\title{
Assessment of the impact of land use change on natural resource land of Srinagar Metropolitan Region of Kashmir Valley
}

\author{
Zahoor A. Nengroo, Arif H. Shah and M. Sultan Bhat
}

\begin{abstract}
Land is the basic natural resource that provides habitat and sustenance for living organisms, as well as being a major focus of economic activities. It is a finite resource and put to many competing uses. In India land is a source of livelihood for $60 \%$ of the population through agriculture and related activities. Urbanization and resultant population growth has led to the consequent demand for land, water and biological resources and has put tremendous pressure on land. The objective of this paper is to document how this urbanization process has expanded throughout the study area and to explore how lands comprising the natural resource base, particularly agriculture and wetlands were lost and replaced by a matrix of the built and other uses of urban demand. The present study was carried out by making use of two time land use/ land cover maps of 1971 and 2010 and associated change due to urbanization was calculated. An extensive accuracy assessments of the satellite-derived maps was conducted, most of which were produced by using widely available multi-temporal Landsat imagery. The change in urbanization was derived from built-up expansion maps (the built environment) for 1971 and 2010, from which the loss in agricultural and wetland resource lands that occurred during the last forty years were calculated. The analysis revealed that there is a fast intrusion of urban activities in the agricultural landscape of the peri-urban areas. Further, wetlands are at the verge of extinction owing to their high susceptibility to encroachment which has not only resulted in threat to their ecology but also reduced their capacity as flood absorption basin.
\end{abstract}

Key words: Urbanization, Multi-temporal, Accuracy Assessment, Impervious, Land sat

\section{INTRODUCTION}

With rapid economic development and population growth, urbanization is taking place at an unprecedented pace around the world, especially in developing countries. (Liu, et al.,2008). Estimates indicate a level of urbanization in the world of only $1.6 \%$ around 1600 A.D. and $2.2 \%$ at the beginning of the $19^{\text {th }}$ century and this is estimated to fluctuate between 4 and $7 \%$ in the mid- $19^{\text {th }}$ century. Today the degree of urbanization exceeds $80 \%$ in developed countries (Antrop, 2004). In the case of developing countries, the level of urbanization is relatively lower, however, the speed of urbanization is five times faster than that of the developed countries (Lopez et.al., 2001).Furthermore, metropolitan population outside central cities has grown faster than downtown areas in many regions, indicating a strong tendency of the outward expansion of urban areas (Angel et al., 2005). In fact, many cities are rapidly growing along their fringes, engulfing vast tracts of natural resource lands (Farmlands, forests and wetlands) and transforming them into industrial and commercial areas, or suburban developments.

In view of rapidly growing cities and sectoral change with a declining contribution from agriculture to the national product and employment, the change of land use from cropland to other forms is increasing rapidly. From 1990 to the year 2020 a total of approximately 14 million hectares (approx.475,000 ha/yr.) in developing countries will be converted for urban purposes (Rosegrant, et al.1997). Even though this loss of potential cropland does not limit agricultural growth globally, in countries like China in which only nine percent of the area can be used for agricultural purposes, major concern about loss of land due to infrastructure and urbanization exists or, at least, should exist. At the same time urban sprawl have changed the land-use/land cover and has resulted in direct ecosystem loss, as well as fragmentation causing decreases in wetland quality and increases in wetland stress (Nathan, et al., 2006). Urban landscape results from the interactions between social and natural factors (Wang, et al., 2008), so urban wetland as a semi-natural ecosystem which is located in high urbanization areas is always interfered by human activities.

The loss of natural resource land to human settlements is far more serious in India; about 1.5 million hectares of land (mostly agricultural) were consumed by uncontrolled urban growth between 1955-1985 and a further 800,000 hectares were expected to be transformed between 1985 and 2000 (Chabra, 1985). The majority of the mountainous population of the Himalaya depends upon agricultural and forest based natural resources for their livelihood (Ramakrishnan,1997) while the resources are sustainably maintained with traditional ecological knowledge (Dollo et al., 2005; Dollo, 2007; Farooquee et al., 2007). 
The objective of this study is to estimate the extent and rates of urbanization (suburban and exurban development) and to assess the impact of this land use change on natural resource lands (agriculture and wetlands) throughout the SMR (Srinagar Metropolitan Region), the largest Himalayan urban centre. Using surface maps to define developed or built areas, in conjunction with land use maps of agriculture and wetlands it is reliable to estimate the increase in urbanization from 1971 to 2010 and quantify the loss of resource lands (agriculture and wetlands) since 1971 associated with this change. Because similar changes are occurring nationwide, even worldwide, this work has wide application and provides techniques and information essential to the land management process for mitigation, prioritization, targeting, and restoration.

\section{STUDY AREA}

Greater Srinagar, the largest among all the Himalayan urban centers is located in the heart of Kashmir valley. The city along with its Rural Urban Fringe is located between the coordinates $33^{\circ} 53^{\prime} 49^{\prime \prime} \mathrm{N}-34^{\circ} 17^{\prime} 14^{\prime \prime} \mathrm{N}$ and $74^{\circ} 36^{\prime} 16^{\prime \prime} \mathrm{E}-75^{\circ} 01^{\prime} 26^{\prime \prime} \mathrm{E}$ (Fig.i). During last 100 years, the city of Srinagar has grown nearly 900 percent in terms of population size and 240 percent in terms of its spatial extent, which has resulted in low density sprawl towards its periphery mainly in the form of leap frog and ribbon development. The main factors responsible for this accelerated population growth during the period have been in migration, increase in birth rates and fall in death rates. Besides this, the merger of 62 villages in municipal limit in 1971A.D. and the introduction of urban agglomeration concept in 2001 have brought a number of rural areas under the jurisdiction of Srinagar city are indeed the other factors contributing to the rapid growth of the city population thereby reducing the population density. Subsequently from 1981 to 2011A.D. the population increased to 971,357 persons in 2001, registering a net growth of 365,355 persons in two decades with a decadal growth rate of 30.14 percent and 1225837 persons in 2011 recording a net addition of 254480 persons during the last ten years. It is pertinent to mention here that no census was conducted in Jammu and Kashmir in 1991 because of political turmoil, therefore population growth was projected for the period

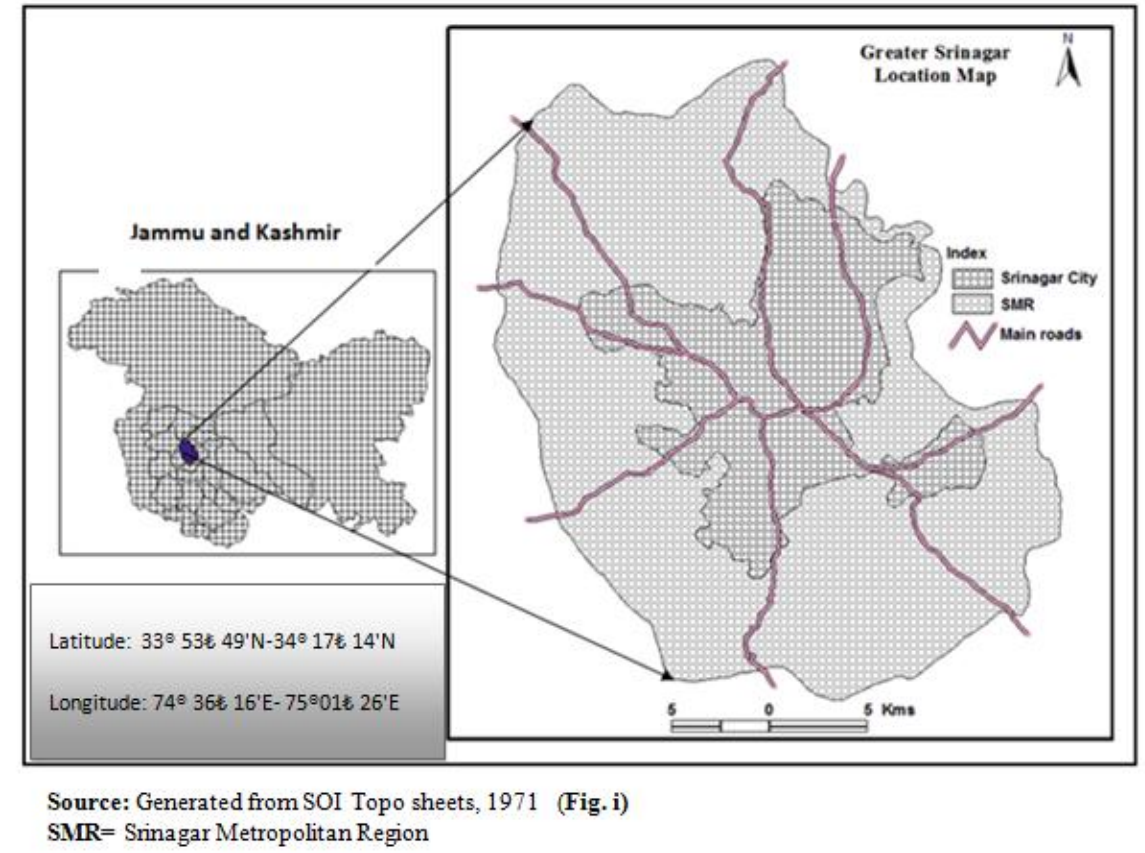

It is situated at an altitude of 5200 feet above mean sea level and spreads over in the midst of an oval shaped valley of Kashmir. The city is encircled by the natural wall of mountains (the sub mountain branches of the pir panjal range) whose height varies from 1800 to 4300 meters above mean sea level. The total area of the Greater Srinagar or Srinagar Metropolitan Region (SMR) city is $1070 \mathrm{kms}^{2}$ with a population of 2085603 persons (census, 2011). The City covers a vast area of Jhelum valley floor characterized by gentle undulating topography, while the south-west and southern peripheries have presence of elevated lands known as kerawas, which occupy large areas in the tehsils of Budgam, Chadura, Pampore and Pulwama. The area suitable for development in the north is limited to the north-west and the south while the eastern extension is limited to the present municipal limits, as the physical extension of the settlements in this area is hindered by Zabarwan hills. 


\section{MATERIALS AND METHODS}

The nature of the study is very diverse; therefore, the data base required and methods involved were very comprehensive and exhaustive which can be briefly shown with the help of a flow diagram.

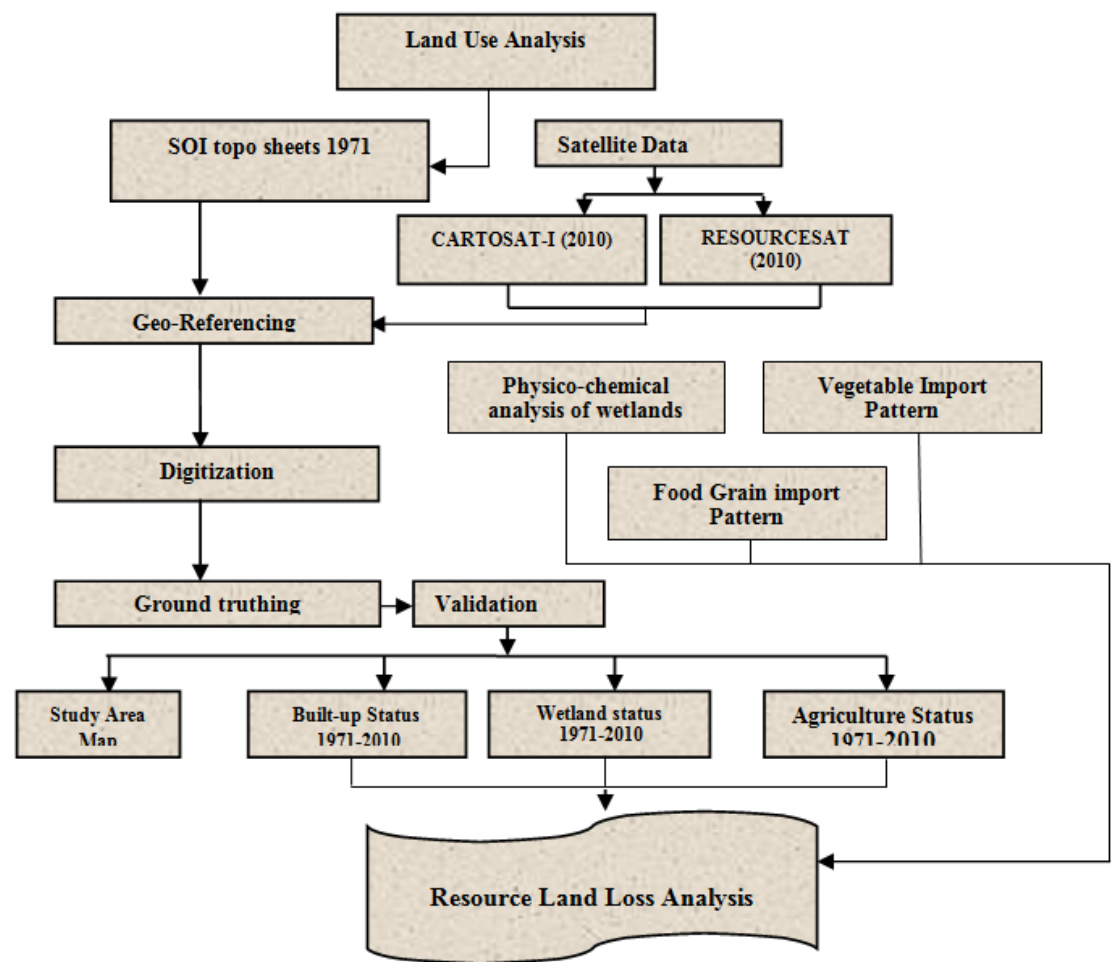

Fig. ii Flow chart showing Methodological Frame adopted for Land Resource Analysis

\section{Results and Discussions}

.The dynamic trend in the population growth of Srinagar city suggests an accelerated rate of growth in city's population in future which is revealed from the fact that the city has achieve the metropolitan status in the year 2008. This anticipated rapid change in the demographic dimension of the city is bound to create an impact on the socio-economic structure of the city and may accentuate the problems of housing scarcity, land speculations and urban blight and slums.

Table 2: Land use/Land cover Change of Srinagar Metropolitan Region (SMR).

\begin{tabular}{cllllccccccc}
\hline Land use & \multicolumn{2}{c}{1971} & \multicolumn{2}{c}{2010} & \multicolumn{4}{c}{ 1971-2010 } & \multicolumn{4}{c}{ Land converted to (\%Age) } \\
\cline { 2 - 12 } Category & $\mathrm{Km}^{2}$ & \%Age & $\mathrm{Km}^{2}$ & \%Age & Growth (\%Age) & Hort & Built-up & Willow & Veg. & Const. & others \\
Agriculture & 704.5 & 66.61 & 481.89 & 44.3176 & -31.72 & 28.5 & 46.5 & 11.3 & 5.2 & 2.7 & 5.8 \\
Wetlands & 81.22 & 7.58 & 46.2 & 4.31 & -43.11 & 0 & 5.1 & 47.1 & 42.6 & 0 & 6.2 \\
Built-up & 704.5 & 6.72 & 481.89 & 15.63 & 132.76 & 0 & 0 & 0 & 0 & 0 & 0 \\
\hline
\end{tabular}

Source: Generated from 1971 topo sheets, Resourcesat and Cartosat-I, 2010.
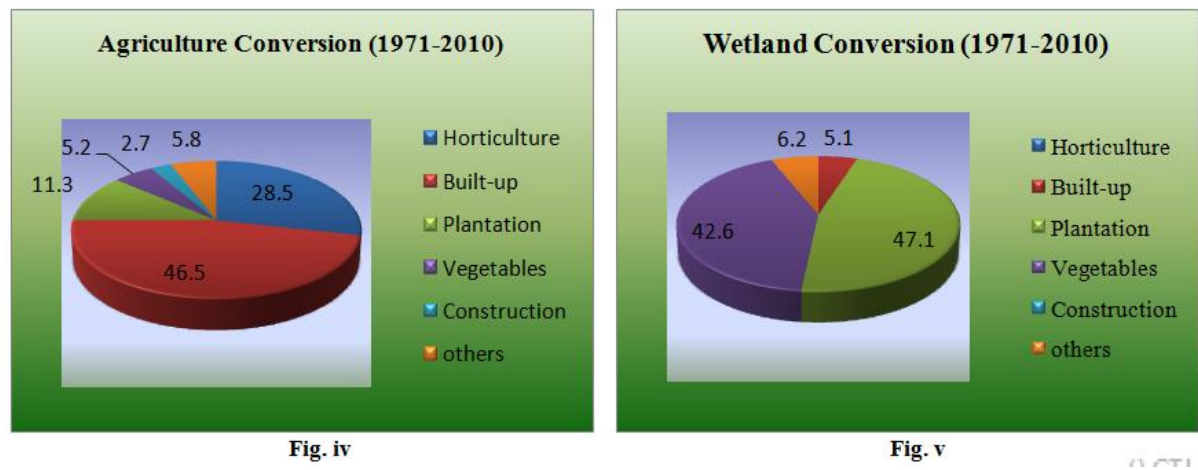
In Srinagar Metropolitan Region, unprecedented population growth and areal expansion coupled with unplanned developmental activities has resulted in rapid but skewed urbanization. This has posed serious implications on the resource land base, access to infrastructure and the development of the region. There has been a continuous transformation of natural resource land base to built-up and other uses which are primarily in response to the demands of the main city.

The built-up has increased from 6.72 percent in 1971 to 15.67 percent in 2010 showing an enormous increase of 132.76 percent. The perusal of table 2 envisages that half of the built-up increased at the cost of agriculture. The conversion of farm lands for residential purposes have negative consequences on food security, water supply as well as the health of the people, both in the cities and in the peri-urban areas. In the city of Srinagar and its environs, there has been a continuous transformation of land from agriculture to builtup and other uses which are primarily in response to the demands of the main city.

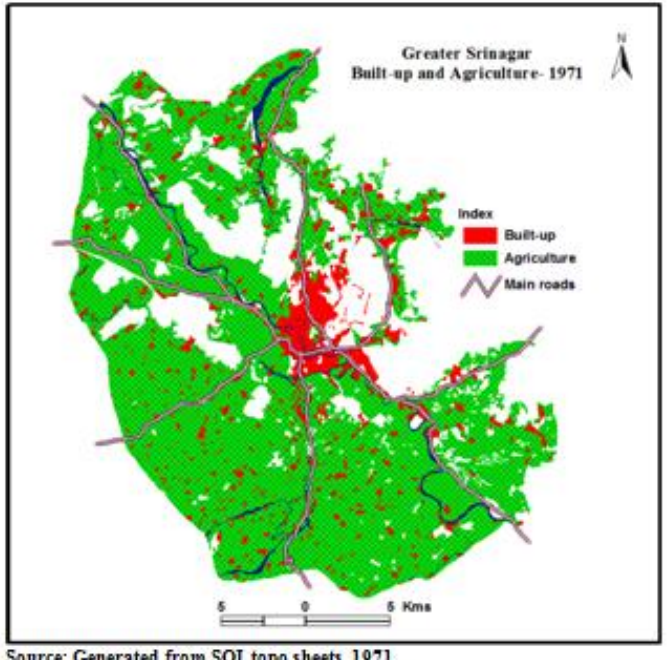

Figure-vi

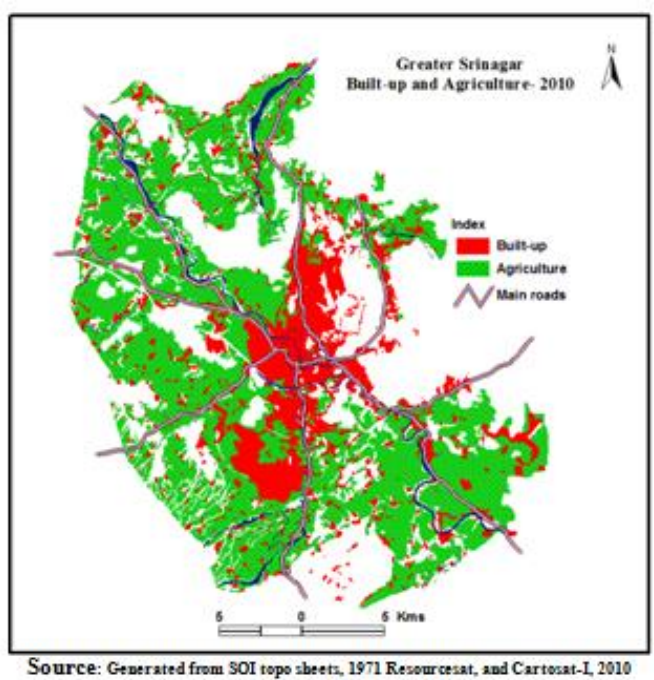

Figure-vii

The figure-vi reveals that natural green categories or agricultural land dominated the land use of 1971 which is further substantiated by the fact as shown in table 2 . The same study area in 2010 , is showing entirely different picture (figure-vii) so for its agriculture is concerned which has got fragmented and reduced drastically to mere 44 percent during the last four decades.
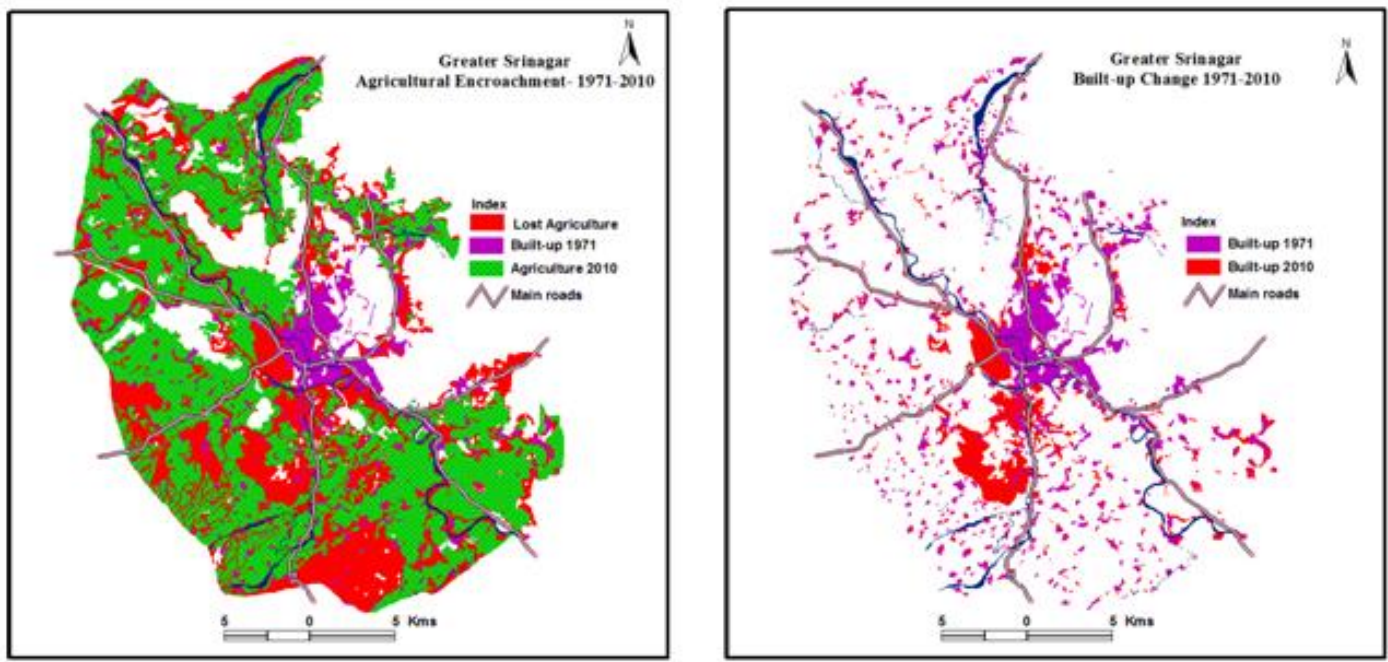

Source: Generated from, SOI topo sheets. 1971, Resourcesat, 2010 and Cartosat-I, 2010. Figure-viii

Figure-ix 
Table 3: Wetland Characteristics and Land Conversion

\begin{tabular}{|c|c|c|c|c|c|c|c|c|c|c|c|}
\hline \multirow[t]{2}{*}{ S.no } & \multirow[t]{2}{*}{ Name } & \multirow[t]{2}{*}{ Location } & \multirow{2}{*}{$\begin{array}{c}\text { Altit } \\
\text { ude } \\
\text { (m) }\end{array}$} & \multirow{2}{*}{$\begin{array}{l}\text { Depth } \\
\text { in }(m)\end{array}$} & \multirow{2}{*}{$\begin{array}{c}\text { Area- } \\
1971\end{array}$} & \multirow{2}{*}{$\begin{array}{c}\text { Area- } \\
2010\end{array}$} & \multirow{2}{*}{$\begin{array}{c}\text { Chan } \\
\text { ge }\end{array}$} & \multicolumn{4}{|c|}{ Transformed into (\%age) } \\
\hline & & & & & & & & $\begin{array}{c}\text { Will } \\
\text { ow }\end{array}$ & $\begin{array}{c}\text { Vegeta } \\
\text { ble }\end{array}$ & $\begin{array}{l}\text { Agricul } \\
\text { ture }\end{array}$ & $\begin{array}{l}\text { oth } \\
\text { ers }\end{array}$ \\
\hline 1 & Hokarsar & $\begin{array}{l}34^{\circ} 05^{\prime} \mathrm{N} \\
74^{\circ} 43^{\prime} \mathrm{E}\end{array}$ & 1580 & $0.5-1.0$ & 17.3 & 10.81 & -37.5 & 48.5 & 22.6 & 23.4 & 5.5 \\
\hline 2 & Mirgund & $\begin{array}{l}34^{\circ} 08^{\prime} \mathrm{N} \\
74^{\circ} 38^{\prime} \mathrm{E}\end{array}$ & 1580 & $0.7-1.2$ & 4.11 & 1.44 & -65.0 & 37 & 51.5 & 8.1 & 3.4 \\
\hline 3 & Narkara & $\begin{array}{l}34^{\circ} 05^{\prime} \mathrm{N} \\
74^{\circ} 43^{\prime} \mathrm{E}\end{array}$ & 1588 & $0.6-1.0$ & 3.48 & 2.81 & -19.3 & 22.1 & 70.6 & 3.5 & 3.8 \\
\hline 4 & Manasbal & $\begin{array}{l}34^{\circ} 05^{\prime} \mathrm{N} \\
74^{\circ} 08^{\prime} \mathrm{E}\end{array}$ & 1587 & $4.5-6.2$ & 2.68 & 2.09 & -22.0 & 65.3 & 8.3 & 24.2 & 2.2 \\
\hline 5 & Shalbugh & $\begin{array}{l}34^{\circ} 10^{\prime} \mathrm{N} \\
74^{\circ} 42^{\prime} \mathrm{E}\end{array}$ & 1580 & $3.0-5.2$ & 15.21 & 7.66 & -49.6 & 47.2 & 43.5 & 6.5 & 2.8 \\
\hline 6 & Khusalsar & $\begin{array}{l}34^{\circ} 05^{\prime} \mathrm{N} \\
74^{\circ} 32^{\prime} \mathrm{E}\end{array}$ & 1584 & $0.7-1.1$ & 1.03 & 0.68 & -34.0 & 22.16 & 72.5 & 4.5 & $\begin{array}{c}0.8 \\
4\end{array}$ \\
\hline 7 & Dal & $\begin{array}{l}34^{\circ} 06^{\prime} \mathrm{N} \\
74^{\circ} 52^{\prime} \mathrm{E}\end{array}$ & 1588 & $3.5-6.2$ & 20.15 & 18.22 & -9.6 & 45.6 & 50.8 & 0 & 3.6 \\
\hline 8 & Nigeen & $\begin{array}{l}34^{\circ} 06^{\prime} \mathrm{N} \\
74^{\circ} 52^{\prime} \mathrm{E}\end{array}$ & 1587 & $4.5-7.6$ & 5.8 & 2.26 & -61.0 & 62.7 & 36.6 & 0 & 0.7 \\
\hline 9 & $\begin{array}{c}\text { Bodsar } \\
\text { Pampore }\end{array}$ & $\begin{array}{l}34^{\circ} 01^{\prime} \mathrm{N} \\
74^{\circ} 56^{\prime} \mathrm{E}\end{array}$ & 1593 & $0.65-0.9$ & 1.54 & 0.46 & -70.1 & 75.2 & 8.5 & 9.1 & 7.2 \\
\hline 10 & $\begin{array}{l}\text { Rakh-i- } \\
\text { Kujar }\end{array}$ & $\begin{array}{l}34^{\circ} 09^{\prime} \mathrm{N} \\
74^{\circ} 37^{\prime} \mathrm{E}\end{array}$ & 1592 & $2.2-3.5$ & 16.31 & 9.95 & -39.0 & 44.5 & 31.6 & 18.7 & 5.2 \\
\hline
\end{tabular}

Source: Generated from SOI toposheets 1971, Cartosat-I, 2010 and modified from Pollution Control Board, Srinagar

Among other resource land categories of the region, wetlands are the most fragile and prone to land transformation. The SMR used to be abode of marshy and wetlands but rapid and haphazard urban sprawl has led to either shrinkage or extinction of majority of these wetlands. These covered an area of 7.58 percent in $1971(81.22 \mathrm{~km} 2)$ and have reduced to 4.31 percent $(46.2 \mathrm{~km} 2)$ in 2010 at an annual loss of -1.14 percent.

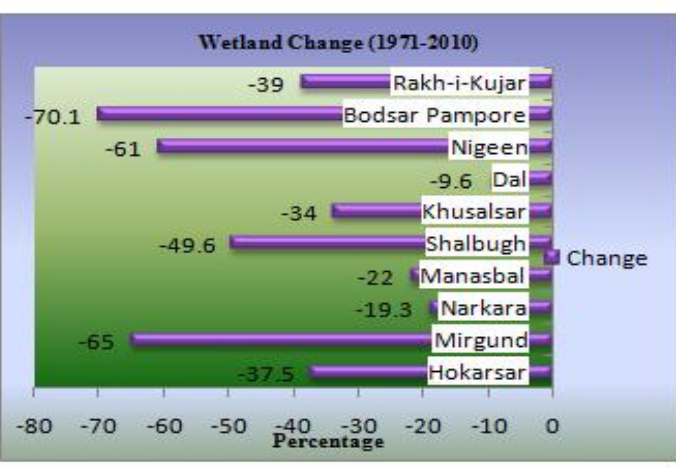

Fig. $x$

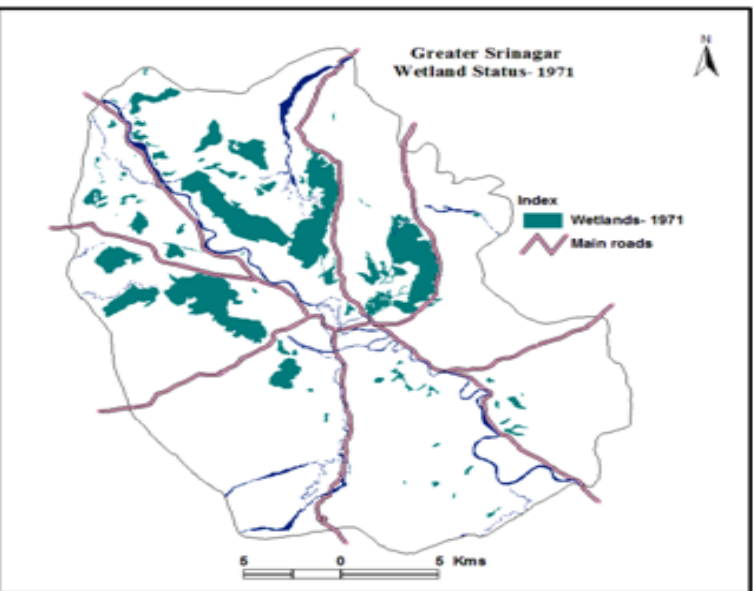

Source: Generated from SOI topo sheets, 1971 sheets, 1971 Resourcesat, and Cartosat-I, 2010

Figure-xii

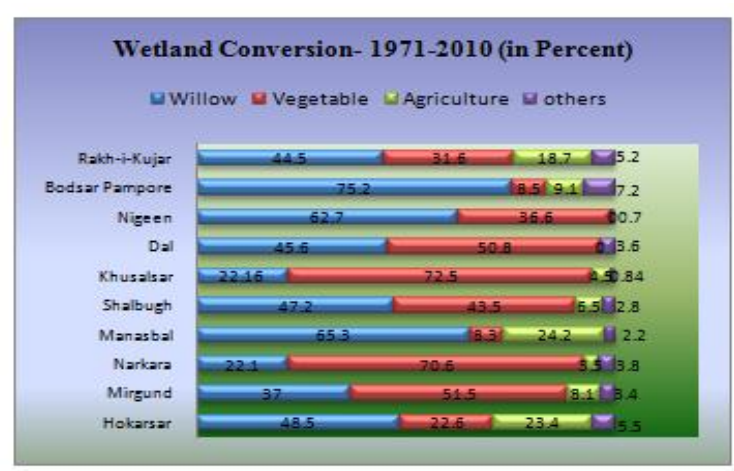

Fig. xi

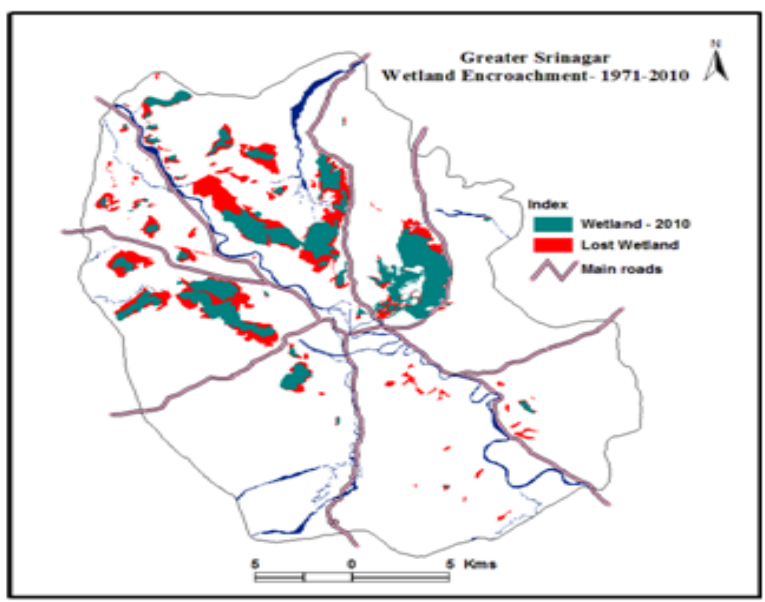

Source: Generated from SOI topo

Figure-xiii 
The analysis of the table III reveals that the wetlands have mainly been encroached by willow plantation and vegetable gardens which are in response to the demands of the city. The unprecedented loss in terms of areal expansion as shown in Fig. xiii has not only resulted in a threat to the wetland ecology but also reduced their capacity as flood absorption basin. Large areas of these wetlands have been lost due to different developmental activities, siltation and encroachments. Further, the remaining area under wetlands has been fragmented as many interconnecting streams have been lost during the period under study.

Cities demand a high input of resources such as food grains, vegetables, milk, fuel wood, timber, water, soil, bricks and other material required for various developmental and constructional activities. The more populous the city the greater is the demand on resources and in general the larger the area from which it is drawn (Hardoy, Mitlin, Satterthwaite, 1992). The expanding urban area of Srinagar city with fast increase in population implies an increasing demand for residential, commercial, industrial and public buildings and other physical infrastructure. Thus, the physical structure of the city requires large amount of construction material and the bulk of material is derived from locally available clay, soil, sand and gravel. This can be seen from the brick kilns concentrated in the kerawas of Srinagar Suburbs as bricks are predominantly used for infrastructure development. Apart from physical infrastructure, the perishable items like vegetables, milk, fruits and flower are the other but crucial city demands which are being provided by the kerawas of the region.

\section{CONCLUSION}

The process of urbanization brings along with it a series of changes, both within and around a city, that initiate consequential developments. In case of Srinagar city growth, there is a fast intrusion of urban activities in the agricultural landscape of the peri-urban areas, from the spillover of the expanding city population caused by rapid urbanization, that changes the occupational structure and the land-use pattern of the entire Srinagar Metropolitan Region (SMR), creating negative impacts on rural practices. Land scarcity has become an increasingly important issue in SMR. Because of rapid land transformation and population growth, the land resource base for agricultural production and wetlands have been shrinking at an alarming rate. Increasing concern over land scarcity is expressed in terms of soil availability for agricultural production which is worsened due to rapid population growth and accelerated urbanization and land transformation over the past four decades. The loss of wetlands in terms of areal expansion has not only resulted in a threat to its ecology but also reduced their capacity as flood absorption basin. Large areas of these wetlands have been lost due to different developmental activities, siltation and encroachments. Further, the remaining area under wetlands has been fragmented and many interconnecting streams have been destroyed

From the above, it is clear that the study area has shown remarkable changes in physical and morphological terms over a period of time. An understanding of the process involved is vital to the city planning. Keeping in view the accelerated rate of resource land transformation, it is imperative that the strong and positive checks should be made and implemented to save the rest of the green space from extinction.

\section{ACKNOWLEDGMENT}

The authors wish to thank University Grants Commission (UGC) for funding the research project entitled "Urban Sprawl of Srinagar City- An impact Assessment Analysis- Using Geo-Spatial Tools". This work was supported in part by a grant from UGC.

\section{REFERENCES}

[1] Angel, S., Sheppard, S.C. and Civco, D.L., 2005, "The Dynamics of Global Urban Expansion" (Washington, DC: Transport and Urban Development Department, the World Bank).

[2] Antrop, M., 2004. Landscape change and the urbanization process in Europe. Landscape and Urban Planning, 67(1-4), pp. 9-26.

[3] Chabra, R., 1985. India: environmental degradation, urban slums, political tension”, Draper Fund report.

[4] Dollo M, Singh KI, Saha D, Chaudhury S, Sundriyal RC., 2005. Livelihood and natural resources utilization pattern in an ethinically diverse area in Arunachal Pradesh. In Bhatt BP and Bujarbaruah KM (eds.), Agroforestry in north east India: opportunities and challenges. ICAR Research Complex for NEH Region, Meghalaya, India, 2005; 55-70.

[5] Dollo M., 2007. Traditional farmers groups supporting sustainable farming. LEISA. 2007; 23(1): 22-24.

[6] Farooquee NA, Dollo M, Kala CP., 2007. Traditional Wisdom of Apatani Community in the management and sharing of natural resources in North Eastern India. In Misra Kamal K (ed.), Traditional Knowledge in Contemporary Societies: Challenges and Opportunities Pratibha Prakashan, Shakti Nagar, Delhi, India, $2007 ; 110-126$.

[7] Hari Srinivas, 2007. Urban Development and Urban Poverty. http://www.gdrc.org/uem/squatters/urbanpoverty.html 
[8] Lopez, E., Bocco, G., Mendoza, M. and Duhau, E., 2001. Predicting land cover and land use change in the urban fringe. A case in Morelia city, Mexico. Landscape and Urban Planning, 55, pp. 271-285.March 27, 1994. p. 1 and 8.).

[9] Ramakrishnan P.S., 1997. Scientific basis of traditional wet rice cultivation by North-East India hills tribes. In Behera MC and Roy NC (eds.), Trends in Agrarian Structure in the Hills of North_East India, Commonwealth Pulblishers, New Delhi, 1997;233-247.

[10] Rees WE (1992), "Ecological footprints and appropriated carrying capacity. What urban economics leaves out", Environment and Urban system, Vol. 4(2), pp. 121-130

[11] Roca, Z., 1993. Urbanization and rural women: Impact of rural-to-urban migration. Rome, United Nations Food and Agriculture Organization, p. 1-10

[12] Rosegrant, M., Ringler, C. \& Gerpacio, R. (1997). Water and Land Resources and GlobalFood Supply,(Paper presented at the XXIII International Conference of AgriculturalEconomists, Sacramento, August 10-17, 1997), Sacramento.

[13] Tyler, P. (1994). Nature and economic boom devouring China's farmland. New York Times

[14] Vink, A. P. A., 1982. Antropocentric landscape ecology in rural areas. In: Perspectives in Landscape Ecology. Contributions to Research, Planning and Management of Our Environment, Center for Agricultural Publishing and Documentation, Wageningen, pp. 